\title{
PERFORMANCE OF R.C. FRAMES COUPLED WITH EXPONENTIAL DAMPERS UNDER SEISMICALLY TRIGGERED CONDITION
}

\author{
Firdous Patel Anjum ${ }^{1}$, L.G. Kalurkar ${ }^{2}$ \\ ${ }^{I}$ PG student, Department of Civil engineering, J.N.E.C, Aurangabad, Maharashtra, India \\ ${ }^{2}$ Assistant Professor, Department of Civil Engineering, J.N.E.C, Aurangabad, Maharashtra, India
}

\begin{abstract}
In the seismically activated areas and in seismically activated conditions, the structure is liable to many forces driving the structure into motion. These forces are large in magnitude and may cause dreadful harm to the structure. Some structural mechanism which reduces the forces acting in such condition and improves the response of these structures by dissipating the forces are called as dampers. In this study effects of use of exponential damping mechanism coupled with structure is studied. Also the response of various finite element models have been shown. It was seen that the response improved by the use of exponential dampers.
\end{abstract}

Keywords: - Dampers, Earthquake, Response, Seismic activity, Time history finite element modelling, ETABS.

\section{GENERAL}

\subsection{Introduction}

Natural hazards such as earthquakes proves to be fatal especially due to damage or collapse of manmade structures such as building bridges and other such infrastructures. This is due to the fact that earthquake carries enormous forces with them which when strikes to the structures results in damage or complete destruction of the structures. There has been many detailed methods which can be used to minimise the destruction caused by such hazards. One of which is the use of mechanical dampers. Dampers proves to be very effective in minimising the magnitude of striking forces. The dampers are explained below:

- Dampers: A device which is used to dissipate the energy induced due to lateral forces resulted because of earthquake are termed as dampers. Every structure have some amount of damping capacity with itself. But it is very difficult to determine the capacity of a structure to dissipate this energy. Hence, Dampers provide more precised and controllable damping for this energy dissipation. Dampers are used in machines, car suspension system and clothes washing machine. Damping system in a building uses friction to absorb some of the forces from vibrations. A damping system is much larger and is also designed to absorb the violent shocks of an earthquake. The behaviour of dampers is dependent on the type of damper used in a structure and the position of its application.

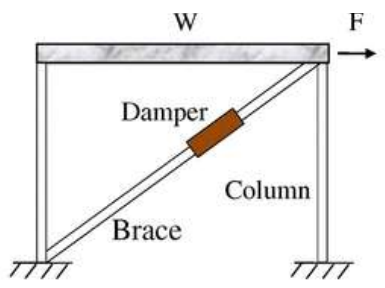

(a)

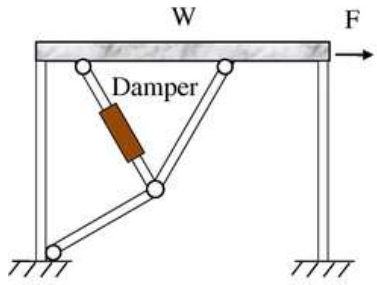

(c)

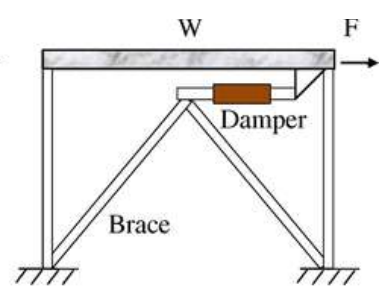

(b)

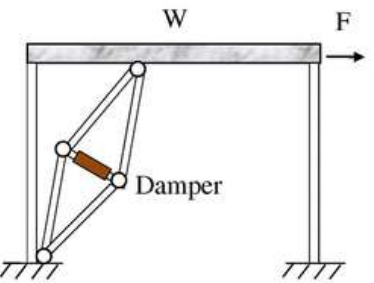

(d)
Fig 1: Arrangements of dampers

- Objective: The objective of this study is to check the influence of exponential dampers in seismically activated condition over the performance of Reinforced concrete frames. For this purpose various models were prepared in ETABS 2016 and analysed for time history.

\section{LITERATURE REVIEW}

- Hyun-Su Kim1, Young-Jin and Kim [1]: Made a study on controlled performance of a shared tuned mass damper (STMD) so as to reduce the activated response of buildings. For this study two eight storied adjacent building structures were considered. These structures were analysed by using Multi-objective genetic algorithm so as to make an optimal design of the stiffness and damping parameters of the STMD. Time 
history data of two earthquakes being, El Centro (1940) and Kobe (1995) were used for structural analyses. Pounding effects of adjacent buildings has also been considered for this study purpose. Based on their numerical solutions and study it was concluded that STMD shows similar control performance as the TMD although the STMD uses only half mass compared to the conventional TMD system. Also the STMD can reduce relative displacement between two example buildings more effectively in comparison with the TMD

- Shubham Mishra, Learin Mathew [2]: Did an investigation on gyroscopic dampers and made a validation of their previous study based on the same. For their study purpose a case study for Taipei 101 was taken where a huge gyroscopic damper, one of its kind has been used. In this case study it was shown that the Taipei 101 which stands only 660ft from a major fault has been designed for major seismic activities and major wind pressures. To compensate the huge vibrations of winds and earthquakes this gyroscopic damper has been used which was tuned mass damper with a heavy mass hanging from the roof of top floors by suspension cables to make a pendulum system. It was lastly concluded that when a gyroscopic damper is used in a structure during lateral activity due to the momentum conservation analogy the building reacts in a compensating manner resulting into stability of the structure.

- Shashank R. Bedekar, Prof. Rakesh Shinde [3]: Performed time history analysis of high rise structures using different accelerograms. In this work an attempt was made to analyse high rise structures with the help of E-tab software. For analysis purpose a high rise structure with G+25 stories was used. Time history data of Bhuj and Koyna earthquakes was used for analysis of selected high rise structure. Comparative study was made between two selected places without $\&$ with provision of visco- elastic dampers. Lastly it was concluded that in previous research papers we can see comparative study between any two types of dynamic analysis. Also we can find specific analysis for selected building plan with changes in various locations, type, shapes of shear wall. In this proposed work we will analyse high rise structure for two different Accelerograms (Bhuj \& Koyna). Comparative study between two time histories can be made without application \& with application of visco- elastic damper at various levels.

- Ankit Jain1, R. S. Talikoti [4]: published a Survey Paper on Study the Performance of High Rise Structure with Dampers at different Location. This thesis describes the results of a study on the seismic behaviour of a structure $(\mathrm{G}+7)$ with and without damper. Equivalent static and non-linear response spectra analysis will be performed on model. Maximum storey deflection, storey drift, maximum moment in column has to be calculated. A RCC G+7 storey building is to be consider for the analysis.
Number of damper to be used will be kept constant, and performance of the structure will be check. Based on result efficient location of damper will be selected. For the analysis Etabs 2013 software is used. behaviour of RC frame building with and without damper under Equivalent static and non-linear response spectra analysis in ETABS - 2013 software. Model-1 building without dampers Model-2 building with dampers at base Model-3 building with dampers at storey-1 Model-4 building with dampers at storey-2 Model-5 building with dampers at storey-3 Model-6 building with dampers at storey-4 Model-7 building with dampers at storey-5 Model- 8 building with dampers at storey-6 Model-9 building with dampers at storey- 7 Conclusions of papers that I had referred 1. Damper help in reducing the effect of lateral deflection. 2 . Seismic performance of building after application of damper is much better when we provide dampers. 3 . The frame is safer when damper is provided as compare with other arrangements. 4. Application of Visco-elastic damper reduces large amount of displacement of the structure. 5. Story drift gets reduced considerably as story displacement is reduced after application of Visco-elastic damper in the building. 6. Base shear reduction one can make the structure cost effective.

\section{SYSTEM DEVELOPMENT}

In this study, three models were modelled in the FEM program ETABS. The plans of all the models were kept to be simple rectangles with total length of building $70 \mathrm{~m}$ in $\mathrm{X}$ direction and total width of building as $50 \mathrm{~m}$ in $\mathrm{Y}$ direction. The bays of the building were kept to be $7 \mathrm{~m}$ long and $5 \mathrm{~m}$ wide. Each side consisted of 10 no. of bays. The material used were M30 grade of concrete and Fe-415 Grade of steel. The other material properties has been shown in the subsequent pages in table. The three models were having the variation as

- $\quad$ Structure-1: G+10 building without dampers

- $\quad$ Structure-2: G+10 building with exponential dampers of weight $=10 \mathrm{kN}$

- $\quad$ Structure-3: G+10 building with exponential dampers of weight $=1 \mathrm{kN}$

The height of the structures and height of each floor were kept constant. The effect of exponential dampers of $10 \mathrm{KN}$ and $1 \mathrm{KN}$ has been checked. The results of which has been stated in subsequent pages. The plans and extruded views has been shown below: 


\begin{tabular}{|l|l|l|l|l|l|l|l|l|l|}
\hline 1 & 1 & 1 & 1 & 1 & 1 & 1 & 1 & 1 & 1 \\
\hline 1 & 1 & 1 & 1 & 1 & 1 & 1 & 1 & 1 & 1 \\
\hline 1 & 1 & 1 & 1 & 1 & 1 & 1 & 1 & 1 & 1 \\
\hline 1 & 1 & 1 & 1 & 1 & 1 & 1 & 1 & 1 & 1 \\
\hline 1 & 1 & 1 & 1 & 1 & 1 & 1 & 1 & 1 & 1 \\
\hline 1 & 1 & 1 & 1 & 1 & 1 & 1 & 1 & 1 & 1 \\
\hline 1 & 1 & 1 & 1 & 1 & 1 & 1 & 1 & 1 & 1 \\
\hline 1 & 1 & 1 & 1 & 1 & 1 & 1 & 1 & 1 & 1 \\
\hline 1 & 1 & 1 & 1 & 1 & 1 & 1 & 1 & 1 & 1 \\
\hline 1 & 1 & 1 & 1 & 1 & 1 & 1 & 1 & 1 & 1 \\
\hline \hline
\end{tabular}

Fig 2: Plan of the building modelled

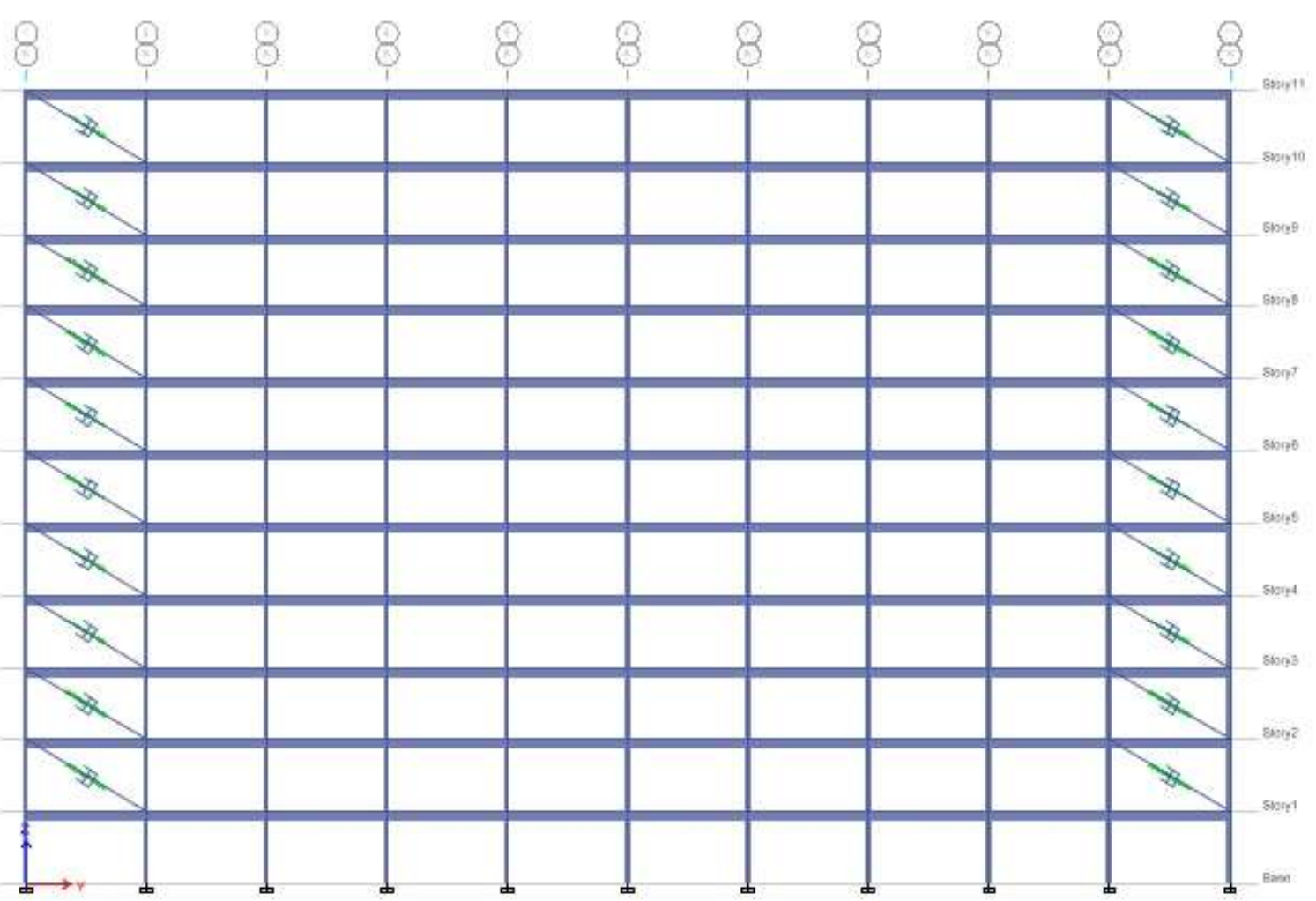

Fig 3: Extruded Sectional View of model with Dampers 


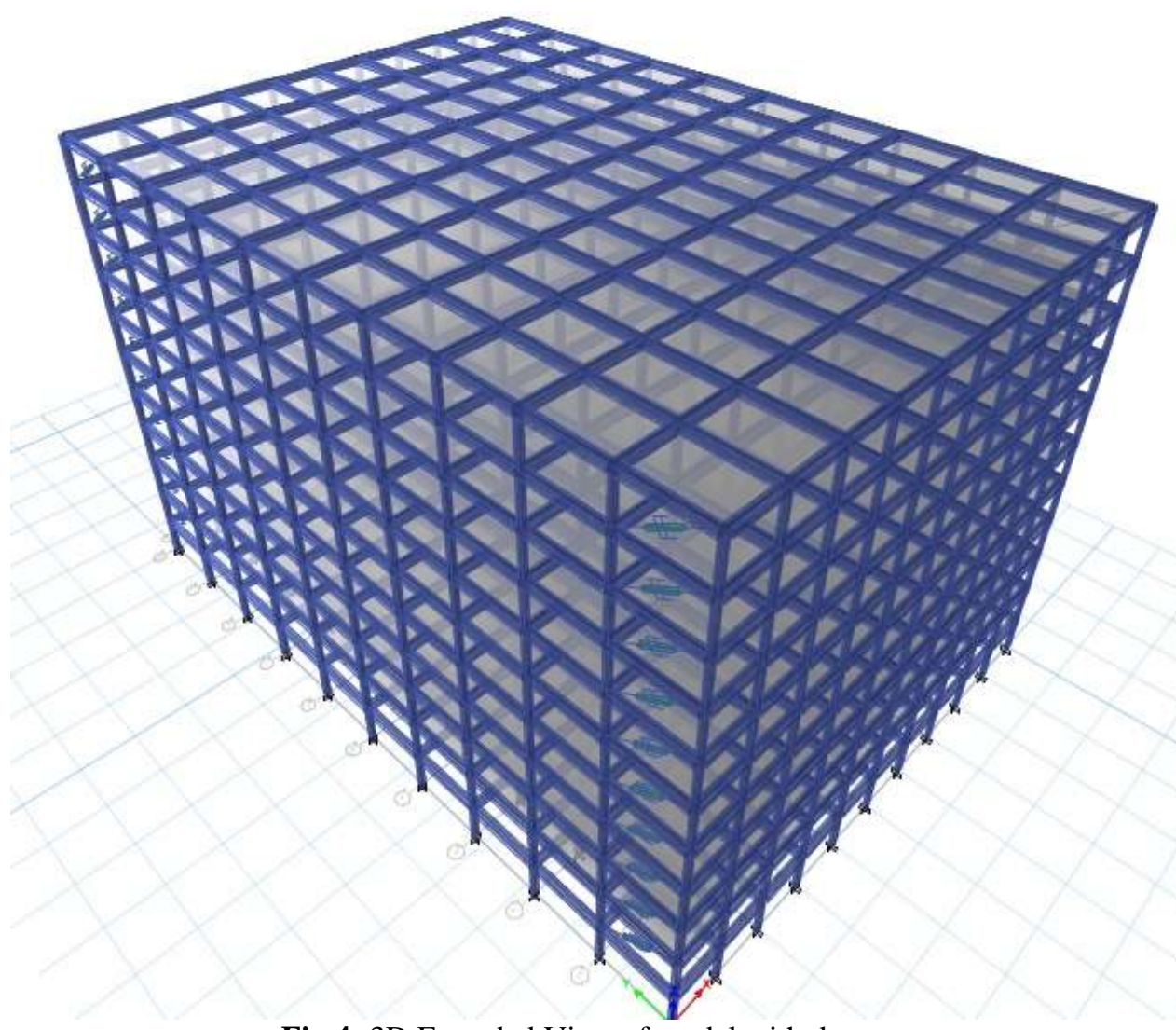

Fig 4: 3D Extruded View of model with dampers

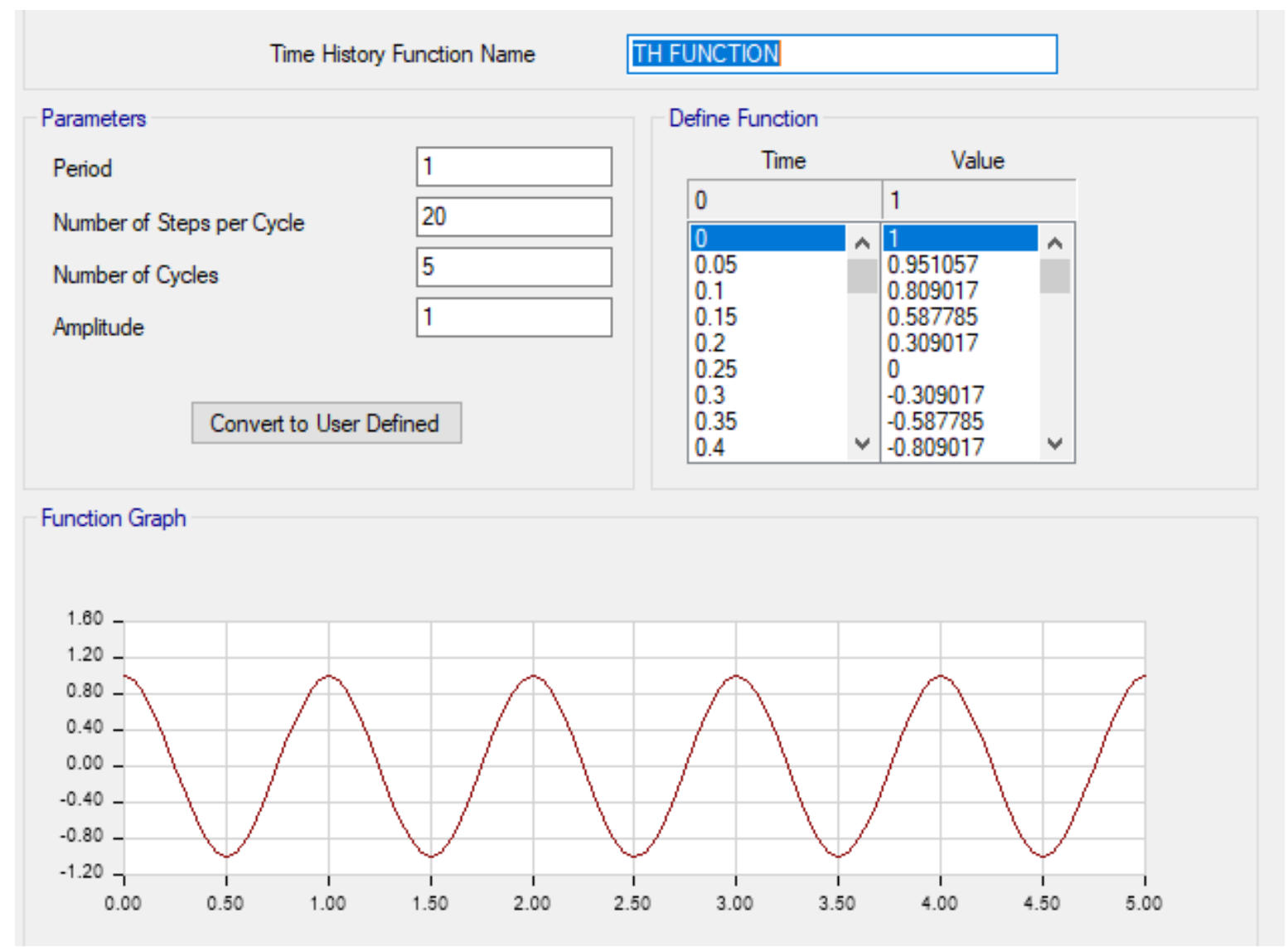

Fig 5: Time history function 
Table 1: Material Properties

\begin{tabular}{|l|l|l|}
\hline 1. & Grade of concrete & $\mathrm{M} 30$ \\
\hline 2. & Grade of reinforcing steel & $\mathrm{Fe}-415$ \\
\hline 3. & Grade of steel & $\mathrm{Fe} 345$ \\
\hline 4. & Density of concrete & $25 \mathrm{KN} / \mathrm{m}^{3}$ \\
\hline 5. & Density of brick masonry & $19 \mathrm{KN} / \mathrm{m}^{3}$ \\
\hline 6. & Damping ratio & $5 \%$ \\
\hline
\end{tabular}

Table 2: General Specification of the Building

\begin{tabular}{|l|l|l|}
\hline 1. & Plan Dimensions & $70 \mathrm{~m} \mathrm{X} \mathrm{50} \mathrm{m}$ \\
\hline 2. & Height of the structure & 46.20 \\
\hline 3. & Height of storeys & $4.20 \mathrm{~m}$ \\
\hline 4. & Thickness of Slabs & $150 \mathrm{~mm}$ \\
\hline 5. & Internal Wall thickness & $150 \mathrm{~mm}$ \\
\hline 6. & External wall thickness & $150 \mathrm{~mm}$ \\
\hline 7. & Depth of footings & $2.5 \mathrm{~m}$ \\
\hline 8. & Type of Support & Fixed \\
\hline
\end{tabular}

Table 3: Structural Specifications

\begin{tabular}{|l|l|l|}
\hline 1. & Type of sections & \multicolumn{1}{l|}{ R.C.C. } \\
\hline 2. & Structure & G+10 \\
\hline Sizes of Column sections & 600 X 600 \\
\hline 2. & Columns (C1) & 300 X 500 \\
\hline Sizes of beam sections & None \\
\hline 3. & Beams (B1) & \\
\hline 4. & Dampers Used & \\
\hline
\end{tabular}

Table 4: Loading Specifications

\begin{tabular}{|l|l|l|}
\hline 1. & Floor load & $1.0 \mathrm{KN} / \mathrm{m}^{2}$ \\
\hline 2. & Live load & $3.0 \mathrm{KN} / \mathrm{m}^{2}$ \\
\hline 4. & External wall load & $18 \mathrm{KN} / \mathrm{m}$ \\
\hline 5. & Internal wall load & $12 \mathrm{KN} / \mathrm{m}$ \\
\hline 6. & Code for RCC & IS $456 \quad(2000)$ \\
\hline 7. & Code for Earthquake analysis & IS $1893(2002)$ \\
\hline 8. & Zone & III \\
\hline 9. & Zone factor (Z) & 0.16 \\
\hline 10. & Importance factor & 1.0 \\
\hline 11. & Moment resisting frame type & OMRF \\
\hline 12. & Response reduction factor & 5.0 \\
\hline 13. & Site soil type & Soft Soil (III) \\
\hline 14. & Analysis Method & Non-Linear \\
& & T.H.A. \\
\hline
\end{tabular}

Table 5: Load Combinations

\begin{tabular}{|l|l|l|l|}
\hline Sr. No & Combination & Sr. No & Combination \\
\hline 1. & $0.9 \mathrm{DL}+1.5 \mathrm{EQX}$ & 8. & $1.5(\mathrm{DL}+\mathrm{EQX})$ \\
\hline 2. & $0.9 \mathrm{DL}-1.5 \mathrm{EQX}$ & 9. & $1.5(\mathrm{DL}+\mathrm{EQY})$ \\
\hline 3. & $0.9 \mathrm{DL}+1.5 \mathrm{EQY}$ & 10. & $1.5(\mathrm{DL}+\mathrm{LL})$ \\
\hline 4. & $0.9 \mathrm{DL}-1.5 \mathrm{EQY}$ & 11. & $1.5(\mathrm{DL}-\mathrm{EQX})$ \\
\hline 5. & $1.2(\mathrm{DL}+\mathrm{LL}+\mathrm{EQX})$ & 12. & $1.5(\mathrm{DL}-\mathrm{EQY})$ \\
\hline 6. & $1.2(\mathrm{DL}+\mathrm{LL}+\mathrm{EQY})$ & 13. & $1.2(\mathrm{DL}+\mathrm{LL}-\mathrm{EQY})$ \\
\hline 7. & $1.2(\mathrm{DL}+\mathrm{LL}-\mathrm{EQY}$ & \multicolumn{3}{|l|}{} \\
\hline
\end{tabular}




\section{RESULTS AND DISCUSSION}

The modelling and analysis of the all the RCC structures has been done finite element based software ETABS 2016. For comparative study of various parameters total three RCC structures were modelled. The parameters such as storey displacement, Storey Shear and overturning moments has been considered for this study. All the seismic parameters which were necessary for the analytical purpose were considered from IS 1893-(1984).

\subsection{Time History Plots}

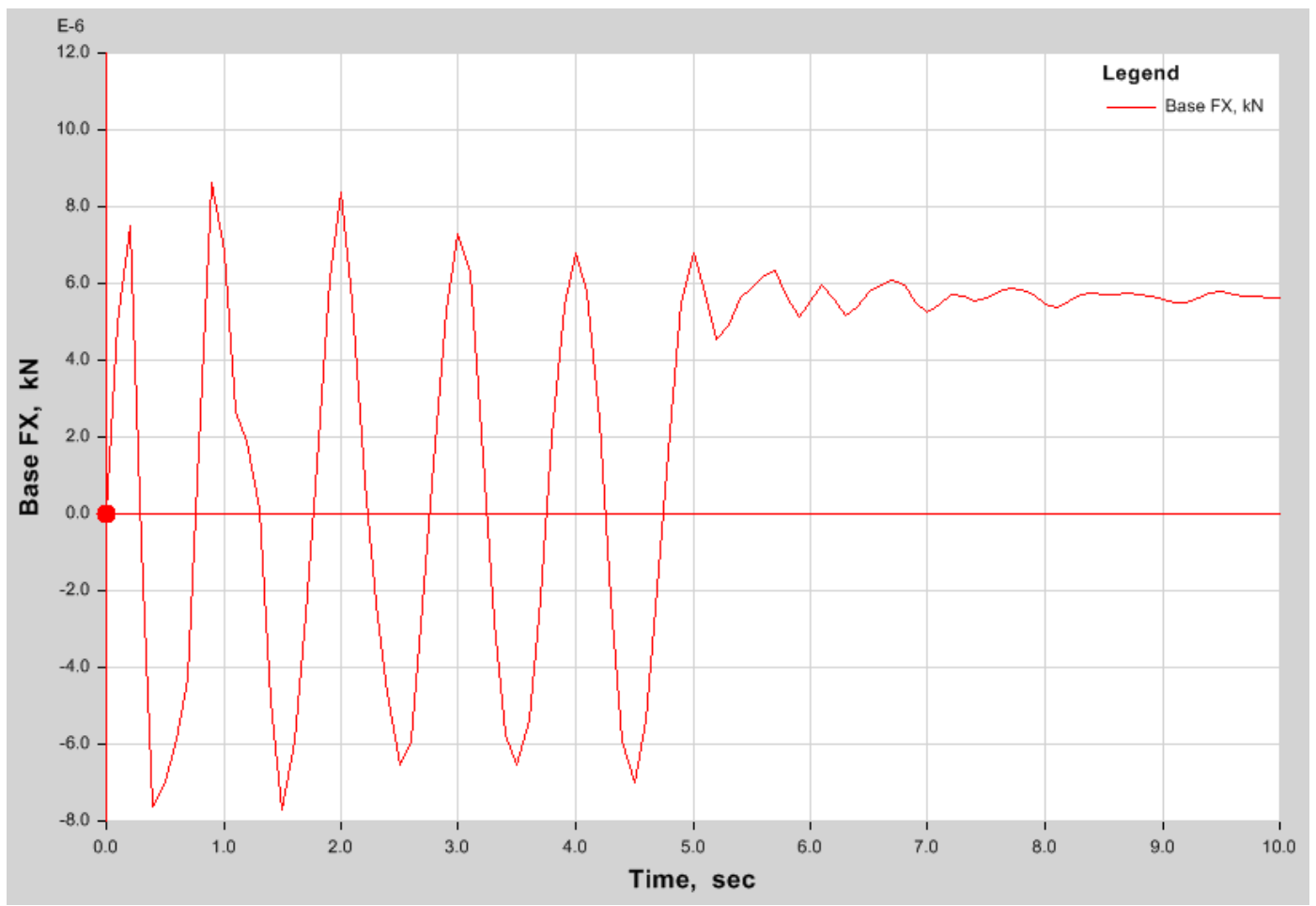

Fig 6: Time History plot for Structure-I

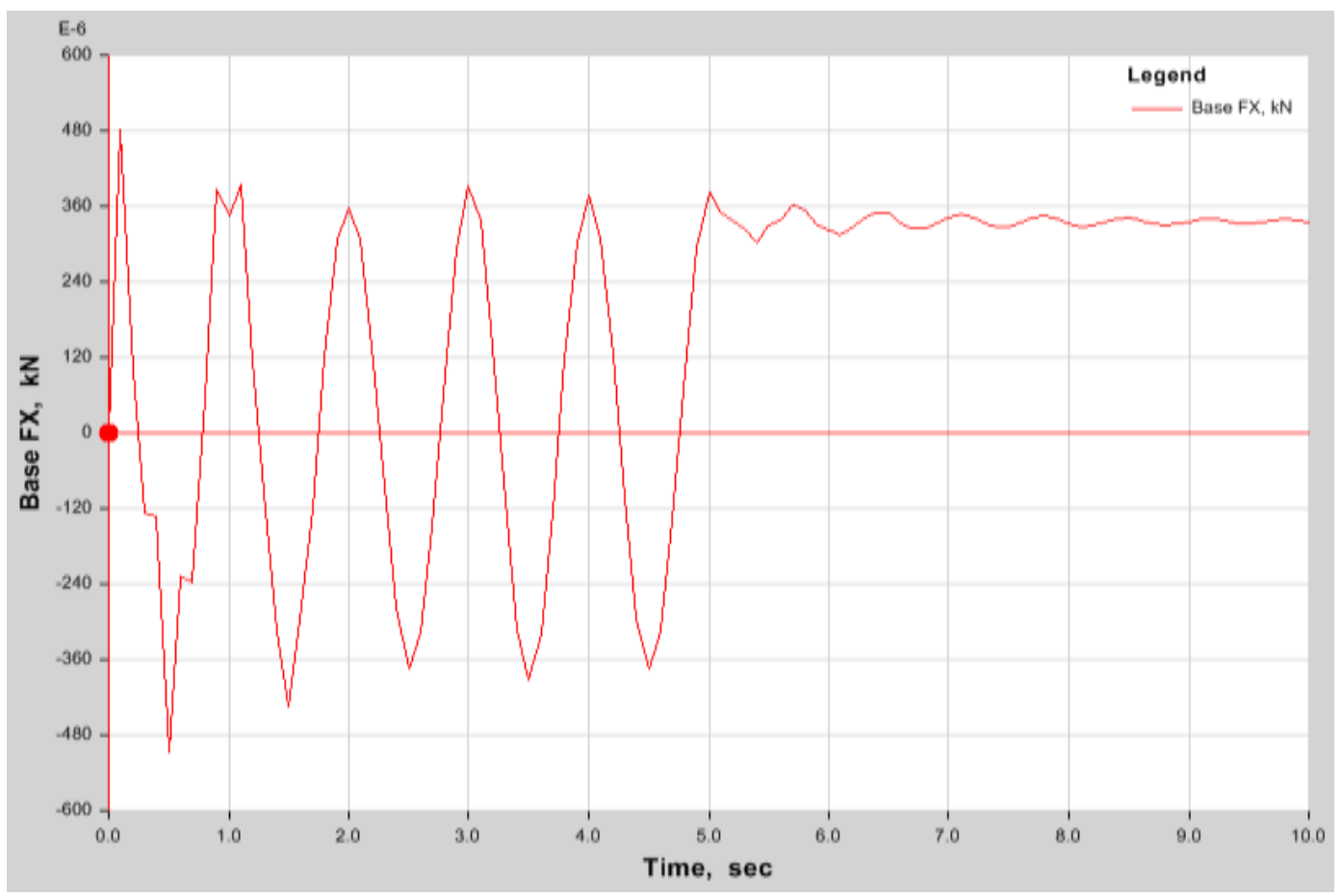

Fig 7: Time History Plot for Structure-II 


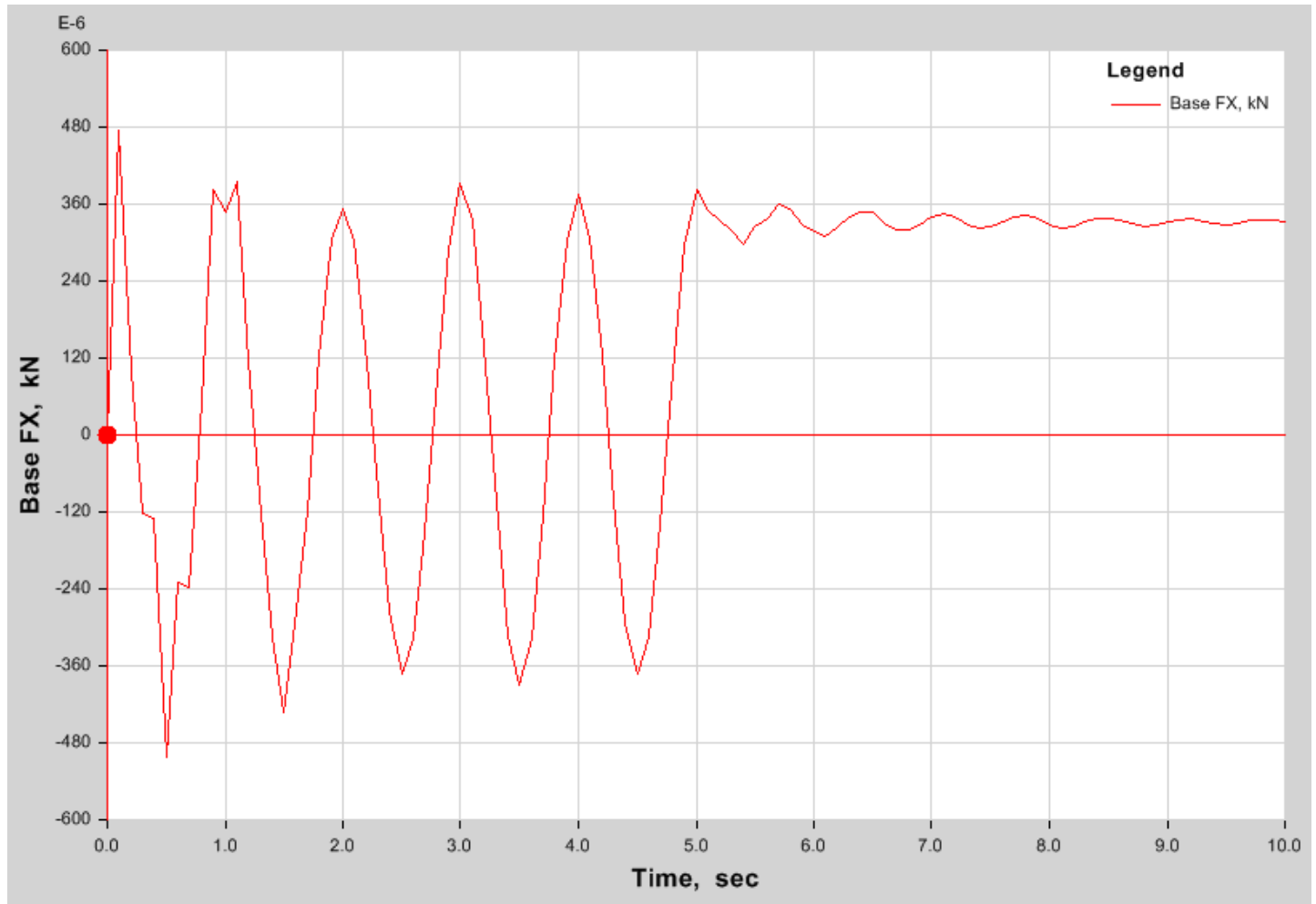

Fig 8: Time History plot for structure-III

The time history plots for all the three structures i.e. structure without damper, structure with damper of capacity/weight $1 \mathrm{KN}$ and structure with dampers of weight $10 \mathrm{KN}$ has been shown in figure 6,7 and 8 respectively. The enormous difference can be clearly seen in all the three plots.

\subsection{Storey Displacements}

The story displacements of all the three structures are further compared to check the performance of the structure. All the displacement graphs has been shown below: 

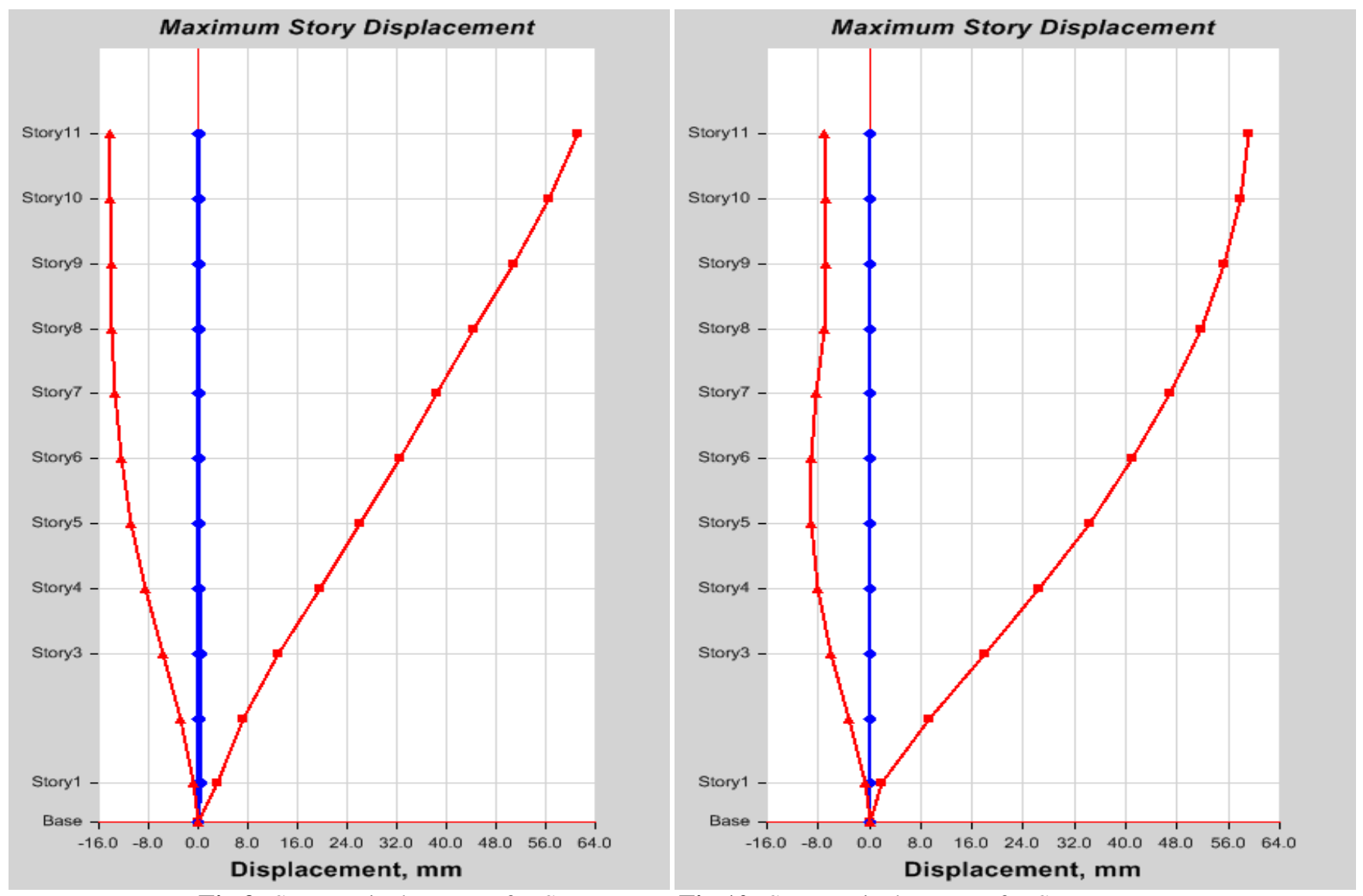

Fig 9: Storey Displacement for Structure-I Fig 10: Storey Displacement for Structure-II

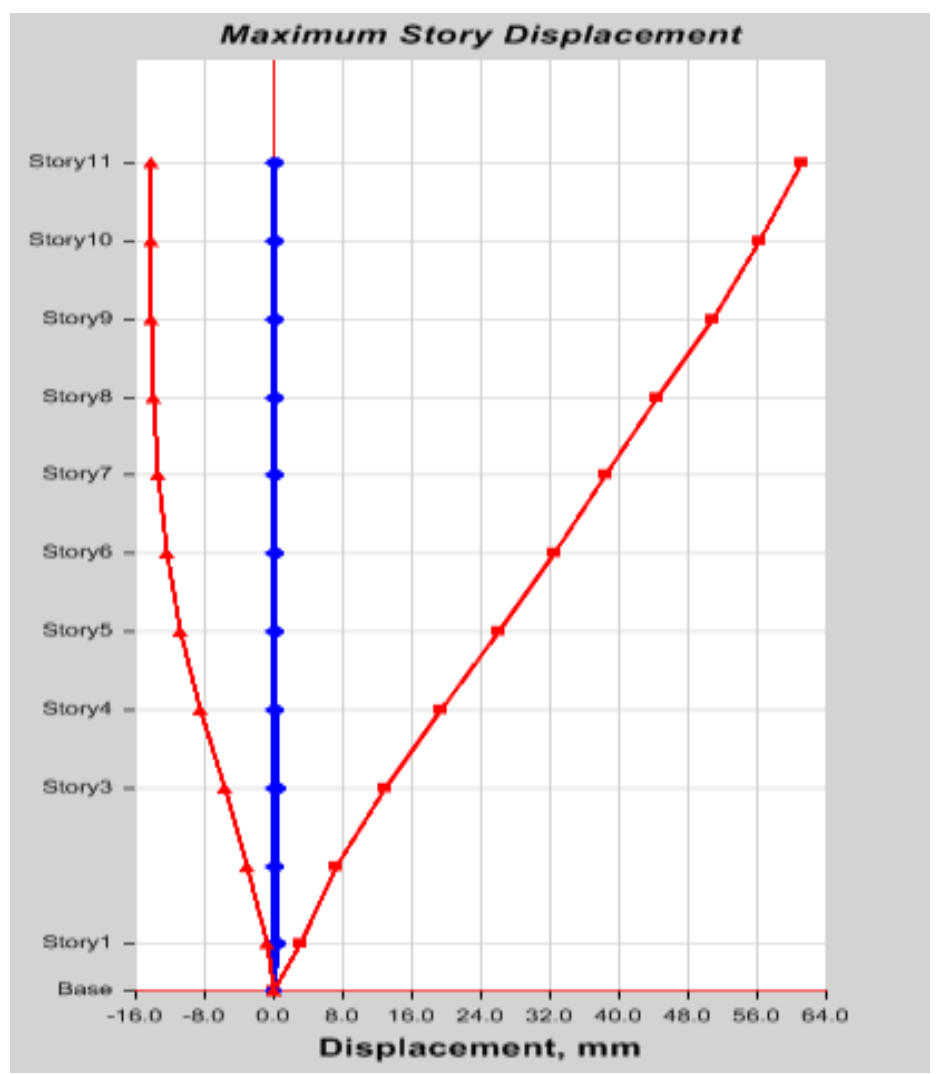

Fig 11: Storey Displacement for Structure-III 


\subsection{Storey Shear}
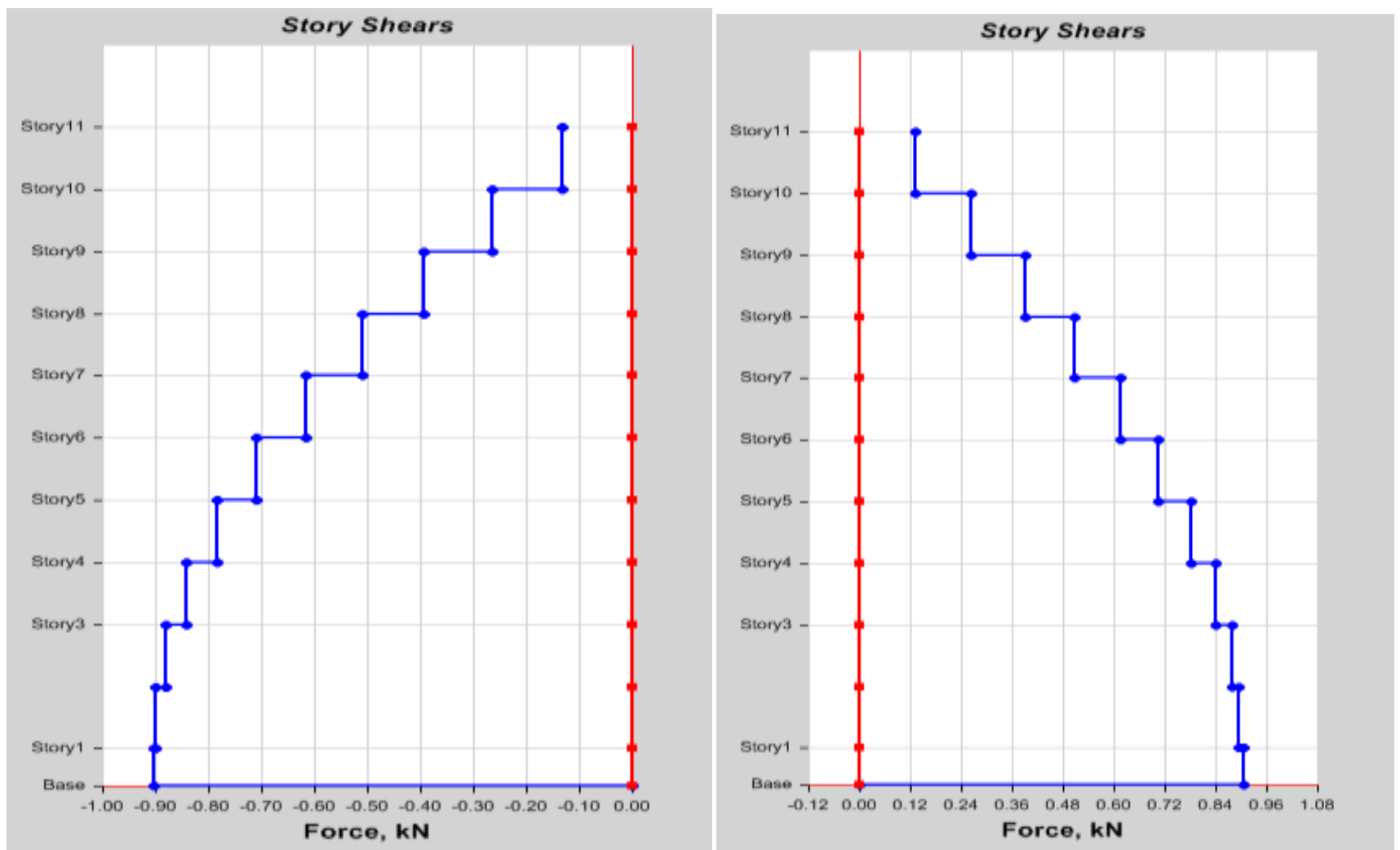

Fig 12: Storey Shear for Structure-I Fig 13: Storey Shear for Structure-II

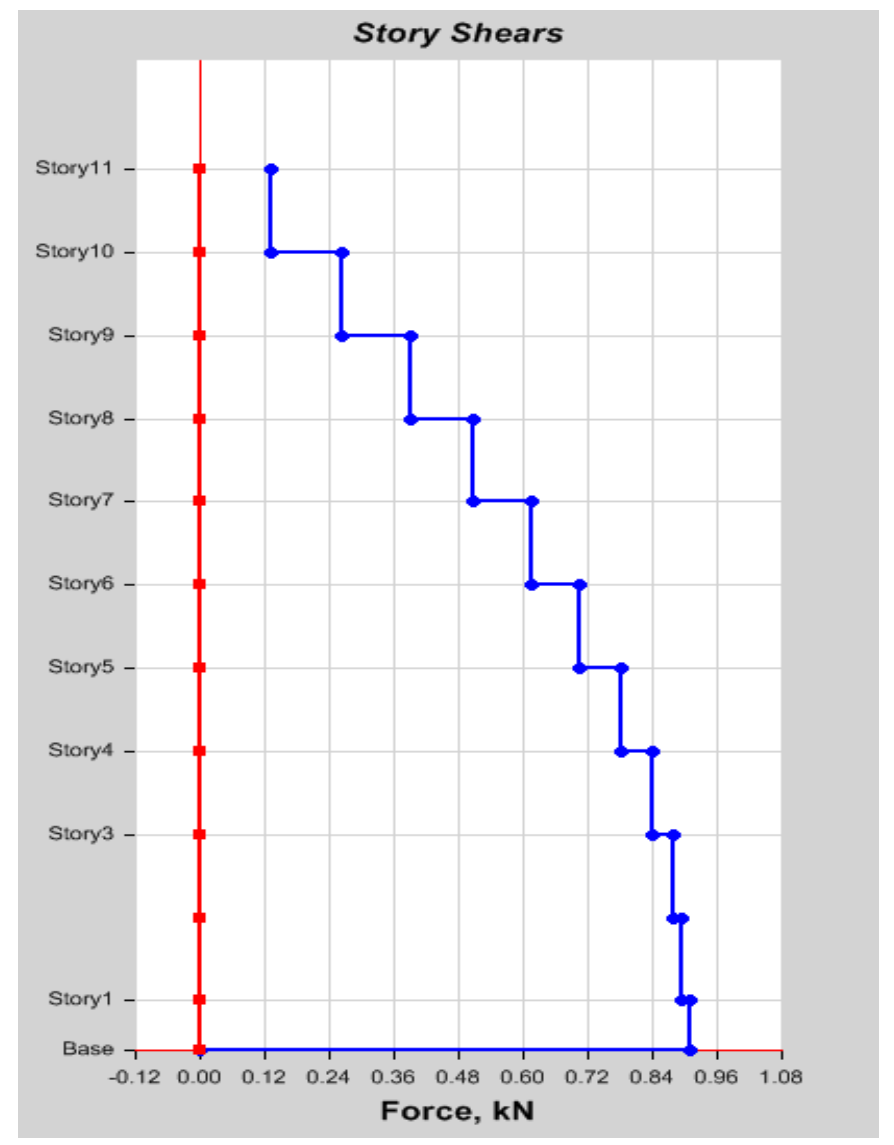

Fig 14: Storey Shear for Structure-III 


\subsection{Overturning Moments}

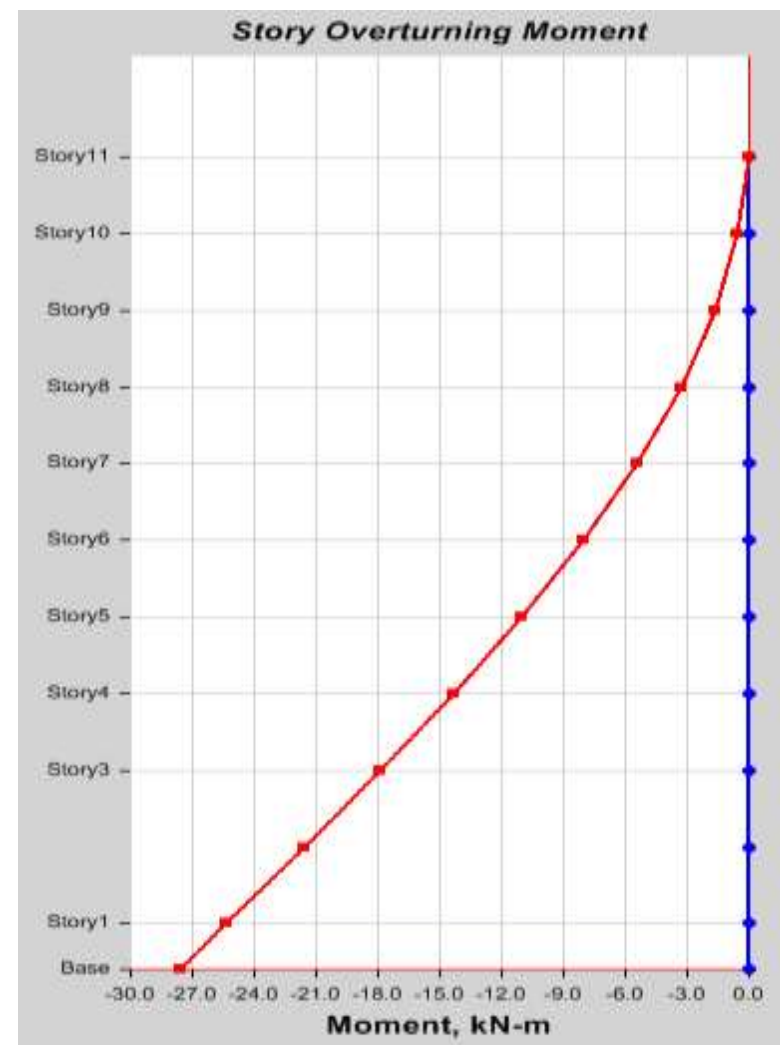

Fig 15: Overturning Moments for Structure-I

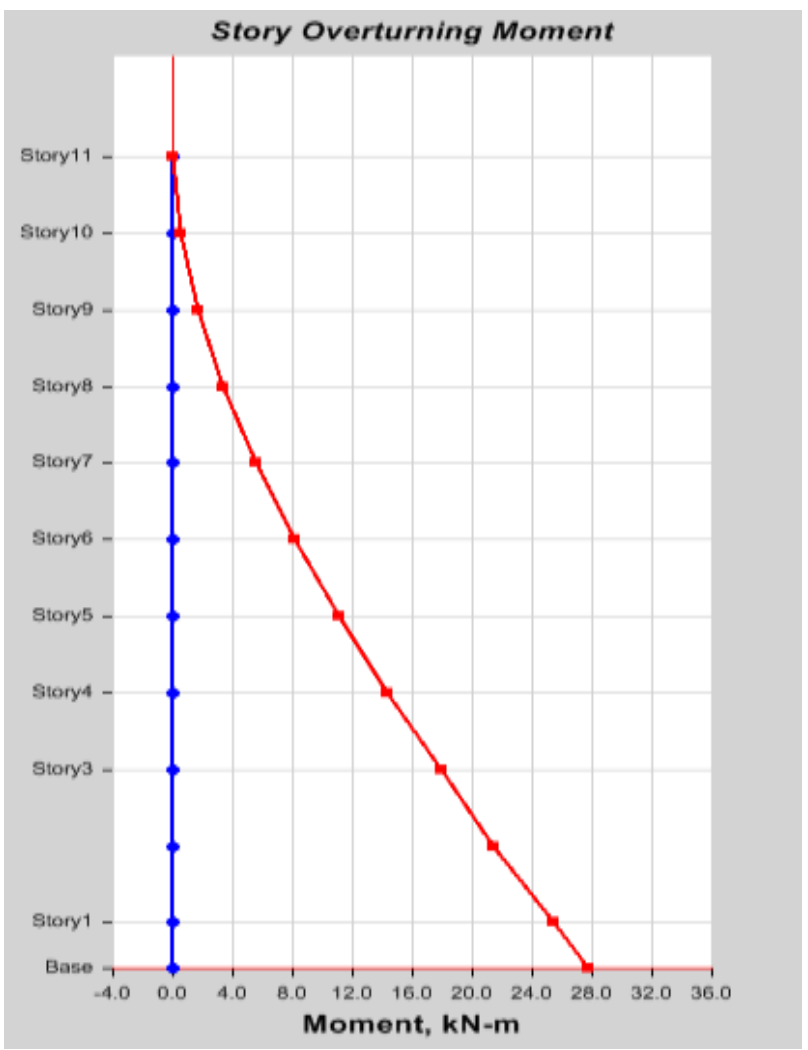

Fig 16: Overturning Moments for Structure-II

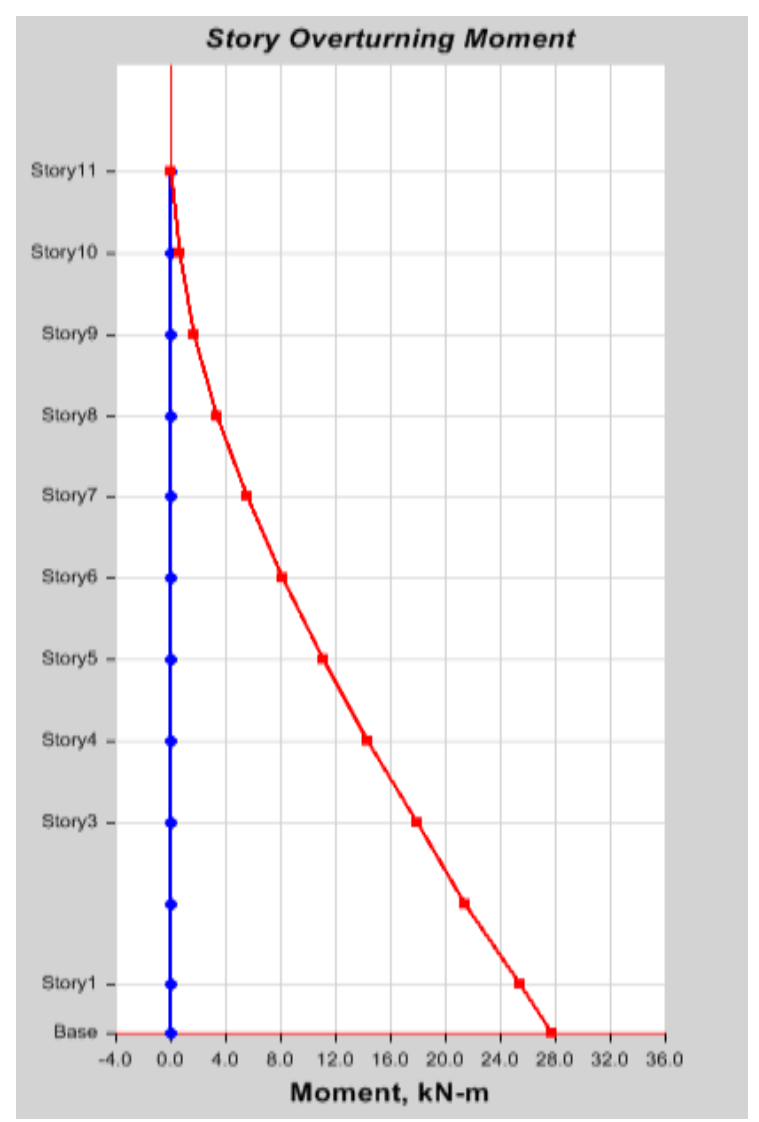

Fig 17: Overturning Moments for Structure-III 


\section{CONCLUSION}

This comparative study has been carried out so as to show the difference between the structures without dampers, with exponential damper of weight $1 \mathrm{KN}$ and with exponential damper of weight $10 \mathrm{KN}$. Based on the study of all the results the following conclusions has been drawn:

- The maximum storey displacements for structure-1, structure-2 and structure- 3 were $16 \mathrm{~mm}, 7 \mathrm{~mm}$ and $14 \mathrm{~mm}$ with the provision of dampers, the storey displacement was reduced by $56.25 \%$ (structure-2) and $12.5 \%$ (structure-3) when compared with structure-1

- Storey shear and overturning moments at base of the structures are constant for structure-1, structure-2 and structure-3.

- Provision of dampers increases time period of the structures, time period for structure-1, structure- 2 and structure- 3 are $2.5 \mathrm{sec}, 3.5 \mathrm{sec}$ and $4.7 \mathrm{sec}$ respectively.

- $\quad$ Time period was increased by $40 \%$ (structure-2) and $88 \%$ (structure-3) when compared with structure-1.

- Base reaction MY, for seismic zone-5 for $(E L+X) \max$ load in structure-I, structure-II and structure-III were 87411.98 KN-m, 86348.98 KN-m and 86240.15 KNm.

- $\quad$ Base reaction MY was decreased by $12.16 \%$ in structure-II and $13.4 \%$ in structure-III, when compared with structure-1

\section{REFERENCES}

[1] IS 1893:1984,"Criteria for earthquake resistant design of structures", Bureau of Indian Standards, New Delhi, India.

[2] IS 456: 2000,"Plain reinforced concrete-code of practice", Bureau of Indian Standards, New Delhi, India.

[3] Hyun-Su Kim, Young-Jinn, Kim, "Control Performance Evaluation of Shared Tuned Mass Damper", Advanced Science and Technology Letters, Vol.69 (Architecture and Civil Engineering 2014), pp.1-4

[4] Shubham Mishra, Learin Mathew, "Case study of tuned mass damper and modelling of gyroscopic damper for corresponding effect", International Journal of Applied Research 2015, Volume-9,Issue1, PP-219-221.

[5] Shashank R. Bedekar, Prof. Rakesh Shinde, "Time History Analysis of High Rise Structure using Different", IJSRD - International Journal for Scientific Research \& Development| Vol. 3, Issue 04, 2015

[6] Ankit Jain1, R. S. Talikoti 2" Survey Paper on Study the Performance of High Rise Structure with Dampers at different Location". 